DOI https://doi.org/10.30525/978-9934-588-91-4-18

\title{
ЛІБЕРАЛІЗАЦІЯ УКРАЇНСЬКОГО СУСПІЛЬСТВА В 1950-Х РОКАХ (ЗА МАТЕРІАЛАМИ ПРЕСИ)
}

\author{
Печеніна Н. А. \\ кандидат історичних наук, доцент, \\ завідувач кафедри історії Украӥни та правознавства \\ Криворізького державного педагогічного університету \\ м. Кривий Ріг, Дніпропетровська область, Украӥна
}

Відновлена 1991 р. державна незалежність України ініціювала трансформацію свідомості політичної та інтелектуальної еліти, широких верств населення, висунула на порядок денний проблему пошуку ідентичності та самоідентифікації. Однією з таких соціально значущих проблем, табуйованою у колишньому Радянському Союзі упродовж багатьох десятиліть, стало дослідження політичних репресій тоталітарної доби. Глибокі деформації в усіх сферах життя суспільства, що відбулися в той час, ми відчуваємо й сьогодні.

Проблема реабілітації жертв сталінізму і тоталітаризму розглядається як складова процесу демократизації і в сучасних умовах залишається актуальною.

Вперше про реабілітацію заговорили після смерті Й.Сталіна у 1953 р., коли в СРСР в цілому та в Україні зокрема розпочалася трансформація соціалізму, що характеризувалася десталінізацією радянського суспільства. Період, пов'язаний зі змінами, що відбувались протягом 1956 - початку 1960-х років, отримав назву «Хрущовської відлиги». В ці роки спостерігалося послаблення компартійних, ідеологічних настанов, активізувалася реабілітація незаконно репресованих громадян, послабилася політика самоізоляції країни, почалася «відлига» в культурному житті. Звичайно, ці зміни не були - і не могли бути - радикальними, послідовними, мали часом суперечливий характер. Але вони якщо й не призводили до кардинальних якісних зрушень у радянській системі, то принаймні визначали нові тенденції в її розвитку.

Практична діяльність з ліквідації наслідків культу особи почалася вже в середині 1953 р. За дорученням ЦК КПРС Комітет партійного контролю зайнявся розглядом справ з реабілітації в партійному відношенні комуністів, притягнутих в 30-40-ві та на початку 50-х рр. до партійної і судової відповідальності. 3 проханням про реабілітацію своїх близьких зверталися дружини і діти радянських, партійних, господарських і військових працівників. Подібні заяви від репресованих 3 проханням про відновлення в партії надходили і в ЦК КП України. Вони передавалися в обкоми партії, де і розглядалися на засіданнях 
бюро обкому. Проте фактичної реабілітації в 1953 р. не відбулося: старі методи і стереотипи партійного керівництва все ще залишалися в силі. У 1954 р. реабілітація торкалася лише окремих осіб, зокрема, В.А. Антонова-Овсєєнко, Я.Б. Гамарника, О.В. Косарєва, М.В. Криленка, П.П. Постишева, В.Я. Чубаря і ін. Незабаром (у 1955 р.) було реабілітовано М.Н. Демченка, В.П. Затонського, Е.І. Квірінга, С.В. Косіора та інших.

Вибіркова реабілітація 1953-1955 рр. розглядалася керівництвом партії єдиним на той час засобом руйнування образу Сталіна, оскільки в принципі ніхто не збирався відрікатися від основних напрямів його політики.

Спроба демократизувати суспільство позначилась також у духовному житті. Першою ластівкою пробудження стала публікація в червні 1955 р. в «Літературній газеті» статті О.Довженка «Мистецтво живопису і сучасність», у якій містився заклик «розширювати межі соціалістичного реалізму» $[2$, с. 1$]$. Заклик знайшов глибоке розуміння й підтримку як в Україні, так і за іiі межами і був сприйнятий як сигнал нових можливостей для вільного творчого пошуку.

Ще більші надії породив XX з'їзд комуністичної партії, на якому після доповіді М.Хрущова було засуджено культ особи Й.Сталіна й висвітлено грубі порушення ленінських принципів національної політики КПРС. Крім того, у резолюції XX з'їзду КПРС стверджувалася необхідність розширення прав союзних республік у господарському i культурному будівництві. Республіканські газети та журнали почали друкувати матеріали, в яких всебічно розглядали постанову ЦК КРПС «Про подолання культу особи і його наслідків». Зокрема, газета «Радянська Україна» на першій полосі вміщує матеріал під назвою «Документ великого історичного значення» [5], в статті «Культ особи суперечить природі соціалістичного ладу» акцентує увагу на перевагах саме радянського устрою, завдяки якому «розквітли дружба народів СРСР та радянський патріотизм» [6]. Останній - у 1956 році - номер газети містив передову статтю, де «колосальним досвідом» року названі рішення XX з'їзду партії, що «відкрили перед нашою Батьківщиною, перед усім могутнім соціалістичним табором... ще ширші й світліші горизонти» [1].

В жовтні 1956 року «Радянська Україна» розміщує біографічний матеріал до 70-річчя 3 дня народження Георгія (Серго) Орджонікідзе, чиє життя обірвалось у 1937 р. та який «тяжко переживав обстановку культу особи та зв'язані з нею порушення норм радянського життя i соціалістичної законності» [3].

Можна констатувати, що в другій половині 1956 р. головним по своїй важливості політичним і соціальним процесом було масове звільнення майже всіх політичних в'язнів з таборів і місць «вічного заслання». Одночасно відбувався такий же масовий і швидкий перегляд 
і реабілітація більшості загиблих в 1937-1955 рр. в'язнів таборів і в'язниць. Більше 90 спеціальних комісій займалися розглядом справ ув'язнених безпосередньо в таборах або місцях їх поселення. Вже до кінця 1956 р. $з$ таборів та заслання повертались колишні члени партії і члени сімей загиблих комуністів. Вийшли на волю також в'язні таборів, чиї терміни ув'язнення закінчилися, але яких продовжували незаконно тримати під вартою. Звільнялися безпартійні, помилково звинувачені в «антирадянській діяльності». 3 таборів повертались колишні члени партій меншовиків, анархістів, есерів, які знаходилися у в'язницях i засланні по 25-30 років. Тобто, реабілітація насамперед торкалась тих осіб, які дожили до цього часу. Реабілітація розстріляних або померлих ув'язнених, як правило, проводилася тільки за заявою родичів або друзів. За відсутності таких заяв в комісії з реабілітації справи репресованих не розбиралися.

На 1 жовтня 1956 р. обкоми КП України розглянули 1302 апеляції. Відновлено в партії було 668 чоловік, частина справ переглядалася в ЦК КПУ, 155 чоловік з 630 було відновлено в партії [8].

На апеляційних засіданнях Дніпропетровського бюро обкому КПУ в 1956 році було розглянуто 134 персональних справ. У партії було відновлено 69 чоловік, виключених в 1937-1939 рр. по звинуваченнях в контрреволюційній діяльності, у зв'язках з ворогами народу, в антирадянській агітації. У 16 випадках реабілітація проводилася за заявами родичів репресованих і була посмертною [4].

Політична відлига фактично спричинила нову хвилю «українізації». Було порушено питання про збереження української мови та розширення сфери ії вживання. Газети «Радянська культура», «Радянська освіта», «Літературна газета» та інші друкували численні листи письменників, учителів, викладачів вищих навчальних закладів із закликами й вимогами поширювати українську мову, боротися за культуру України, підносити красу й милозвучність рідного слова. На захист української мови виступили відомі письменники.

Дедалі більше уваги стали приділяти збереженню культурної спадщини. В жовтні 1956 року газета «Радянська Україна» розмістила репортаж львівських спецкорів Д.Дереча та Я.Тумаркіна до 700-річчя Львова «Місто науки і культури», в якому розкривались історичні вехи розвитку Львова та акцентовано увагу на важливому археологічному відкритті: при розкопках кам'яного фундаменту замку, що його збудував Казимир III, «виявлено більш стародавні стіни. Вони складені 3 великих глиб природного каменю і зцементовані тією самою масою, яка застосовувалась в кам'яних спорудах Київської Русі» [7]. На думку професора I. Крип'якевича, тогочасного директора Інституту суспільних наук, укріплення Львова були закладені саме на горі Високий замок. В репортажі підкреслювалась увага влади до 
«міста-музея» та іï зусилля щодо збереження архітектурних та історичних цінностей Львова.

Прикладом дбайливого ставлення до культурної спадщини стає те, що під охорону держави в Україні в 50-ті роки було взято понад 2 тис. визначних пам'яток історії [3, с. 3].

Проте вже з кінця 1962 р. посилюється ідеологічний диктат у духовній сфері, починається масовий послідовний ідеологічний тиск на ту частину інтелігенції, яка вийшла 3-під тотального контролю, придушуються громадські ініціативи «шістдесятників». У суспільному житті, особливо в культурно-ідеологічній сфері, відбувається процес згортання «відлиги».

\section{Література:}

1. 1956-й. Радянська Украӥна. 1956. 30 грудня.

2. Баран В., Даниленко В. «Відлига» в культурному житті УРСР на зламі 50-60-х рр. Історія Украӥни. - 2001. - № 17 (травень).

3. Видатний діяч Комуністичної партії і Радянської держави. До 70-річчя 3 дня народження Г.К.Орджонікідзе. Радянська Украӥна. 1956. 28 жовтня.

4. Державний архів Дніпропетровської області. Ф. 19, оп. 30, справи $17,30$.

5. Документ великого історичного значення. Радянська Украӥна. 1956. 4 липня.

6. Культ особи суперечить природі соціалістичного ладу. Радянська Україна. 1956. 24 липня.

7. Місто науки і культури. До 700-річчя Львова. Радянська Україна. 1956. 23 жовтня.

8. Центральний Державний архів громадських об'єднань України. - Ф. 1, оп. 31, ч. 1, сп. 329, арк. 171-174 